\title{
Sustainable Project Life Cycle Management: the need to integrate life cycles in the manufacturing sector
}

\author{
Carin Labuschagne ${ }^{a}$ \\ Alan C. Brent ${ }^{\text {b }}$ \\ ${ }^{\mathrm{a}}$ Department of Engineering and Technology Management, University of Pretoria, \\ Room 4-12, Engineering 2, Pretoria 0002, South Africa \\ ${ }^{\mathrm{b}}$ Department of Engineering and Technology Management, University of Pretoria, \\ Chair: Life Cycle Engineering, South Africa
}

\section{Abstract}

The pressure on businesses to incorporate the principles of sustainable development into policies and activities is mounting. Project management methodologies are not excluded from this pressure. The current project management frameworks do not effectively address the three goals of sustainable development, i.e., social equity, economic efficiency and environmental performance. A prerequisite for aligning these frameworks with the principles of sustainable development is a clear understanding of the various life cycles involved in a project and the interactions between these life cycles. The way forward to achieve true Sustainable Project Life Cycle Management in the manufacturing is subsequently outlined.

\section{Article Outline}

1. Introduction

1.1. The reaction of business to the sustainability challenge

2. Current status of Project Life Cycle Management 
3. Defining life cycles in the manufacturing sector

3.1. Project life cycle

3.2. Asset life cycle

3.3. Product life cycle

4. Sustainable Project Life Cycle Management: the way forward

4.1. Identifying measurable indicators for the sustainability evaluation criteria

4.2. Further work required

References

\section{Introduction}

The World Commission on Environment and Development (WCED)s report in 1987 is viewed as a major political turning point for the concept of sustainable development [1]. Since then the influence of the concept has increased extensively and it features more and more as a core element in policy documents of governments and international agencies [1]. The World Summit on Sustainable Development (WSSD) in 2002 highlighted this growing recognition of the concept by governments as well as businesses at a global level [2].

The concept of sustainable development is nevertheless inherently vague [3]. The first formal definition of the concept appeared in the 1987 WCED report (later published as a book "Our Common Future") as "development that meets the needs of the present without compromising the ability of future generations to meet their own needs" [4]. There are currently over 100 definitions of sustainability and sustainable development, but most agree that the concept aims to satisfy social, environmental and economic goals. These goals are also referred to as the three pillars or objectives of sustainable development [5], [6] and [7]. Although the concept is thus understood intuitively it remains difficult to express it in concrete, operational terms [8].

Business, as one of the three pillars of society (the other two being government and civil society) [9], has a responsibility towards the whole of society to actively engage in the 
sustainability arena [10]. The pressure is therefore mounting for businesses to align operational processes with the three objectives of sustainable development [11]. Four different types of drivers for the incorporation of sustainability in business practices have been identified [12]. An adaptation of the identified drivers is illustrated in Fig. 1.

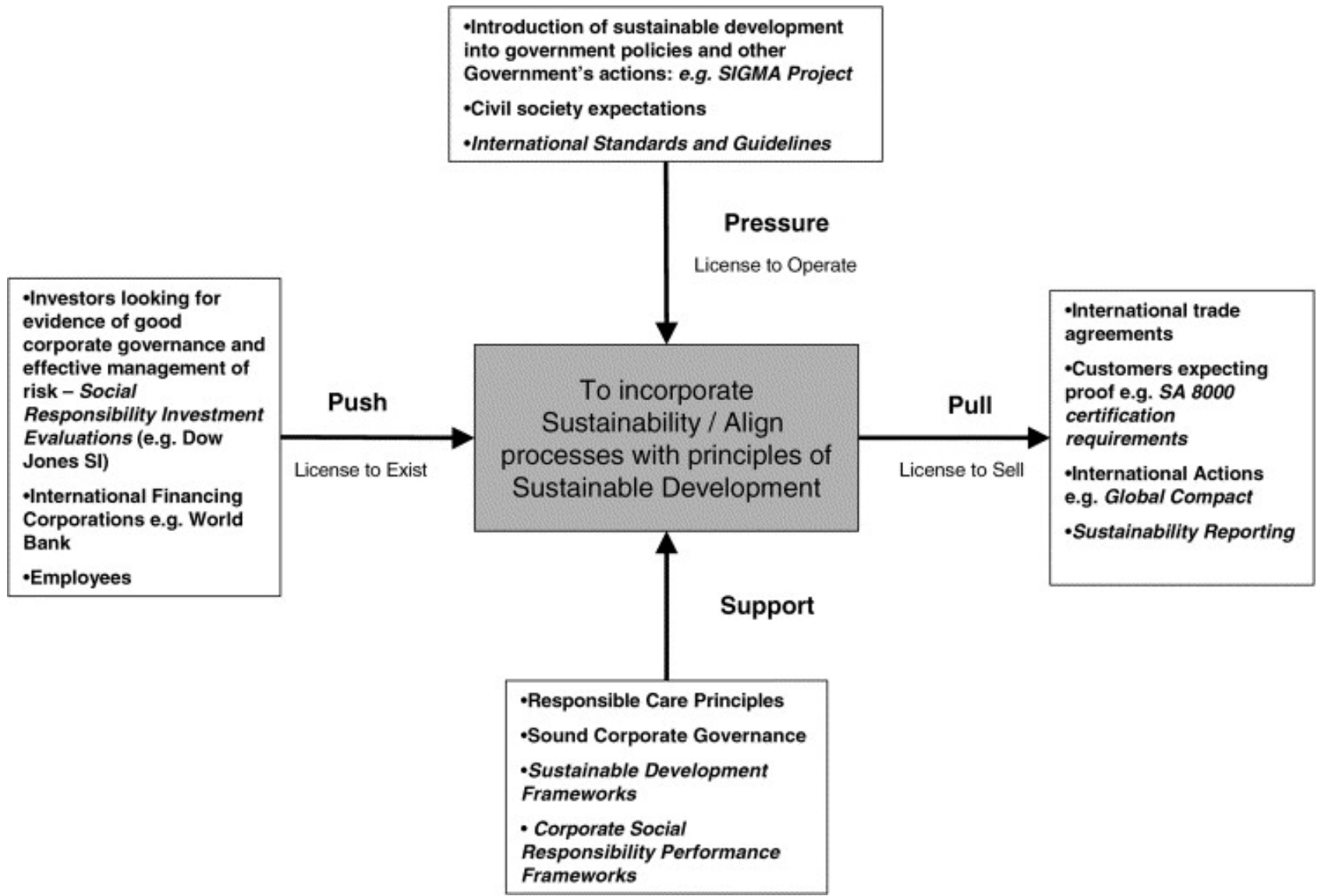

Fig. 1. Drivers for the incorporation of sustainable development in business practices. In order to assist business, the International Institute for Sustainable Development (IISD) has suggested the following definition of sustainable development for the business community: "For the business enterprise, sustainable development means adopting business strategies and activities that meet the needs of the enterprise and its stakeholders today, while protecting, sustaining and enhancing the human and natural resources that will be needed in the future” [13]. 


\subsection{The reaction of business to the sustainability challenge}

Three levels within an organisation have been identified that can be subjected to change namely, the Strategic Level, Process or Methodological Level and the Operational Level [14]. In order for sustainability to manifest within a company, change needs to take place on all three levels. This is, however, not currently the case. On a strategic and operational level there are evidence of the integration of sustainability into the business environment. Some companies have started to define sustainable development for their business, while others endorse international agreements or include the principles of sustainable development in the company's vision and mission statements. The majority of emphasis has fallen on the operational level where companies implement Environmental Management Systems and report on the sustainability of their operations in annual sustainable development reports. Companies also tend to place an increasing importance on corporate social responsibility and corporate philanthropic projects.

However, the 2002 PricewaterhouseCoopers Sustainability Survey [15] revealed that of the 101 Fortune 1000 companies that were interviewed, $72 \%$ of the respondents do not include the risk and/or opportunities of sustainability in their project, investment and transaction evaluation processes. Research by IWOe-HSG has further revealed that traditional business management systems are solely geared towards financial performance and therefore exclude environmental and social sustainability aspects [16]. Fig. 2 illustrates the statistics from the 2002 PricewaterhouseCoopers Sustainability Survey [15]. The second level of change that is required for an overall sustainability focus (as is shown in Fig. 2), i.e., business processes and methodologies, thus largely ignores environmental and social sustainability aspects. 


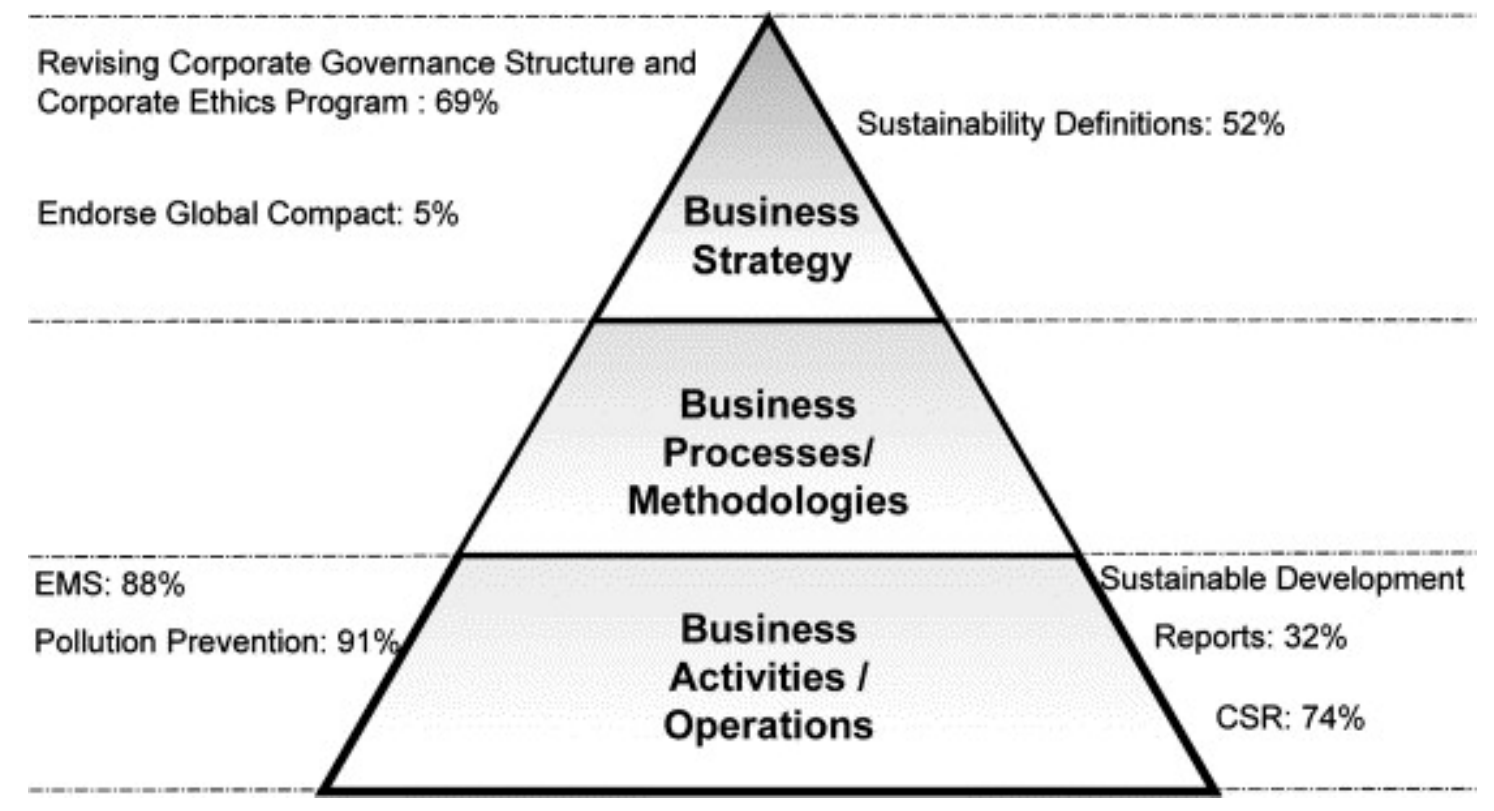

Fig. 2. Incorporation of sustainability within different levels in an organisation.

The traditional top-down and bottom-up approaches to incorporate sustainability within the organisation have not seemed to be effective to a large extent. Practical tools, which systematically include sustainability within the evaluation processes, are needed to align business methodologies with the principles of sustainable development [17]. Project management methodologies, which are a core business methodology of most companies, are not excluded from this requirement. Furthermore, companies are also increasingly accountable for the impacts of an implemented project on the society, environment and economy long after the project has been completed, i.e., beyond the normally considered project life cycle [18]. Therefore, current project management methodologies need to be reviewed (in the manufacturing sector context) to ensure alignment with and incorporation of sustainability aspects as well as life cycle management principles.

\section{Current status of Project Life Cycle Management}

The nature of project management has changed since the 1960s. Companies in the new millennium are managing projects on a far more informal basis with less paper work by 
relying on techniques such as "checklists for end of phase reviews". Critical to these informal project management approaches are an appropriate methodology and an understanding of the life cycle phases [19].

A benchmarking study [20, p. 17] supports these concepts by concluding that companies, which are successful in project management, all use a company-specific, simple and welldefined project management framework that defines a staged approach for all projects under all circumstances. The framework specifies major activities and deliverables for each project phase as well as guideline questions for the phase end reviews or gates. These specifications of deliverables and activities establish a level of management control [18].

Nevertheless, the current theoretical frameworks do not efficiently take social and environmental issues into account. An analysis of the project management frameworks in the South African process industry [21] revealed that most frameworks address environmental impacts to a limited extent by following the formal guidelines of the national Department of Environmental Affairs and Tourism (DEAT) for conducting Environmental Impact Assessments (EIAs) [22] during some of the project life cycle phases. Social aspects are not mentioned in the activities, deliverables or gate review questions of the frameworks [21]. Furthermore, the project appraisal process does not efficiently address all sustainability aspects either, since the emphasis of the project appraisal process is on financial and technical viability, and the social and environmental aspects are considered to lie outside the normal appraisal process [23]. Moreover, the traditional project appraisal approach can lead to outcomes that are unacceptable from the point of view of intergenerational fairness [24], which is one of the core principles of sustainable development.

It is thus evident that the current project management frameworks require revision. Also, there is a definite need to develop indicators that can be used in decision-making processes to ensure that projects are managed according to practices that will contribute to sustainable development [25]. However, a prerequisite for Sustainable Project Life 
Cycle Management is a clear understanding of the various life cycles involved in a project and their interactions.

\section{Defining life cycles in the manufacturing sector}

A project can be defined as a temporary undertaken that has a specific objective and a definite beginning and end [19]. The $\mathrm{PMBOK}^{\circledR}$ guide [18, p. 4] defines a project as “ $a$ temporary endeavour undertaken to create a unique product or service”. If these definitions of a project are taken as a departure point it can be said that the project itself will have minimal economic, environmental and/or social consequences, but that it will be the "product" or deliverables of the project that will have these consequences and impacts. This concept is supported in the financial analyses of projects where the financial implications of the project's deliverables are included in the profitability, Return on Investment (ROI) and Net Present Value (NPV) calculations [26].

As projects in the manufacturing sector are the focus of this paper, a project can be seen as a vehicle to implement the capital investment in a new or improved asset. Since the asset is used to manufacture products, there are thus three distinct life cycles involved: project life cycle, asset/process life cycle, and product life cycle.

\subsection{Project life cycle}

Various project life cycle approaches exist in the literature, e.g., control-oriented model, quality-oriented model, risk-oriented model, a fractal approach to the project life cycle, as well as some company-specific project life cycles [27]. The number of phases within each of these approaches differs as well as the names used to describe the phases. Due to the complex nature and diversity of projects, industries, or even companies within the same industry sector, cannot reach agreement about the life cycle phases of a project [19, p. 76]. It has subsequently been proposed that the theoretical system life cycle phases should be applied to a project, which are: Conceptual, Planning, Testing, Implementation and Closure [19]. 
Table 1 summarises seven generic life cycle phases in a project that have been proposed [20], together with a basic description and alternative names for each phase. This generic project life cycle can be tailored to suit the requirements of individual projects and it does happen that phases are combined, e.g., the development and execution phase is often combined with the commissioning phase. Based on these literature proposals, as well as interviews that have been conducted in the South African manufacturing industry, the project life cycle that is illustrated in Fig. 3 is used for the remainder of this paper.

\section{Table 1.}

Life cycle phases in a project [20]

\begin{tabular}{|c|c|c|}
\hline Phase names & $\begin{array}{l}\text { Alternative } \\
\text { names }\end{array}$ & Description of phase \\
\hline \multirow[t]{4}{*}{ Idea generation } & Proposal & $\begin{array}{l}\text { In this phase the idea for a new project is generated and the } \\
\text { initial proposal that describes the business need must be } \\
\text { prepared. This phase does not require a formal project plan }\end{array}$ \\
\hline & Concept & \\
\hline & Initiation & \\
\hline & Ideation & \\
\hline \multirow[t]{5}{*}{ Pre-feasibility } & $\begin{array}{l}\text { Initial } \\
\text { investigation }\end{array}$ & $\begin{array}{l}\text { The goal of this phase is to evaluate the existing proposal in } \\
\text { terms of financial, operational and technical viability as well as } \\
\text { against the company's strategy. Overlapping or synergy with } \\
\text { other projects should also be checked out }\end{array}$ \\
\hline & Initial assessment & \\
\hline & $\begin{array}{l}\text { Preliminary } \\
\text { investigation }\end{array}$ & \\
\hline & Evaluation & \\
\hline & Research & \\
\hline \multirow[t]{2}{*}{ Feasibility } & $\begin{array}{l}\text { Detailed } \\
\text { investigation }\end{array}$ & $\begin{array}{l}\text { The optimum solution to address the business need must be } \\
\text { identified and defined. All areas of this solution must be } \\
\text { analyzed and assessed to determine killer concerns and risks }\end{array}$ \\
\hline & Definition & \\
\hline
\end{tabular}




\begin{tabular}{|c|c|c|}
\hline Phase names & $\begin{array}{l}\text { Alternative } \\
\text { names }\end{array}$ & Description of phase \\
\hline & Business case & \\
\hline & Evaluation & \\
\hline & Authorization & \\
\hline \multirow[t]{6}{*}{$\begin{array}{l}\text { Development and } \\
\text { execution }\end{array}$} & Implementation & $\begin{array}{l}\text { This phase involves design, development, creation and building } \\
\text { of the chosen solution. The supporting system, manuals, } \\
\text { business processes and training for the solution must also be } \\
\text { developed during this phase }\end{array}$ \\
\hline & Realization & \\
\hline & Production & \\
\hline & Construction & \\
\hline & Build & \\
\hline & Develop and test & \\
\hline \multirow[t]{3}{*}{ Commissioning } & Trial & $\begin{array}{l}\text { In this phase the solution is tested in an operational } \\
\text { environment. The purpose is to validate the acceptance and } \\
\text { capabilities of the solution }\end{array}$ \\
\hline & Beta test & \\
\hline & Validation & \\
\hline \multirow[t]{5}{*}{ Launch } & Release & $\begin{array}{l}\text { The project is handed over to the business units and thus } \\
\text { released to the operational environment during this phase. This } \\
\text { phase also marks the beginning of operational support }\end{array}$ \\
\hline & Completion & \\
\hline & Implementation & \\
\hline & Handover & \\
\hline & Acceptance & \\
\hline Post & Business review & After sufficient time (9-15 months) the project should be \\
\hline
\end{tabular}




\begin{tabular}{|l|l|l|}
\hline Phase names & $\begin{array}{l}\text { Alternative } \\
\text { names }\end{array}$ & Description of phase \\
\hline $\begin{array}{l}\text { Implementation } \\
\text { Review (PIR) }\end{array}$ & $\begin{array}{l}\text { assessed to determine if the benefits were delivered and what } \\
\text { the impact of the project was on the business. Lessons learned } \\
\text { should be captured for future reference }\end{array}$ \\
\hline & Project audit & $\begin{array}{l}\text { Post project } \\
\text { review }\end{array}$ \\
\hline
\end{tabular}

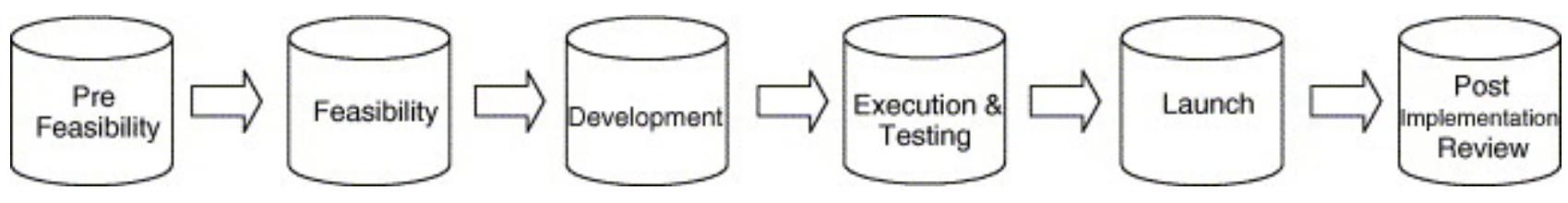

Fig. 3. Project life cycle.

\subsection{Asset life cycle}

The project life cycle and asset life cycle are often viewed as one life cycle due to the fact that the two life cycles contribute to the same value chain. Nevertheless, there are a definite difference between a project and an operational activity (or asset) as can be seen in Table 2 [28]. It has been argued that the traditional system life cycle phases [29] could be applied to an asset [30]. The asset life cycle will thus consist out of six phases, as is shown in Fig. 4.

\section{Table 2.}

Characteristics of a project and an operational activity [28]

\begin{tabular}{|l|l|}
\hline Project & Operational activity \\
\hline • Produces a new specific deliverable & $\bullet$ Delivers some product \\
\hline • A defined start and end & $\bullet$ Continuous \\
\hline • Multidisciplinary team & $\bullet$ Specialized skills \\
\hline • Temporary team & $\bullet$ Stable organization \\
\hline • Uniqueness of project & $\bullet$ Repetitive and well understood \\
\hline • Work to a plan within defined costs & $\bullet$ Work within an annual budget \\
\hline
\end{tabular}




\begin{tabular}{|l|l|}
\hline Project & Operational activity \\
\hline • Canceled if objectives cannot be met & $\bullet$ Continual existence almost assured \\
\hline $\begin{array}{l}\text { • Finish date and cost more challenging to predict and } \\
\text { manage }\end{array}$ & $\begin{array}{l}\text { • Annual expenditures calculated based on past } \\
\text { experience }\end{array}$ \\
\hline
\end{tabular}

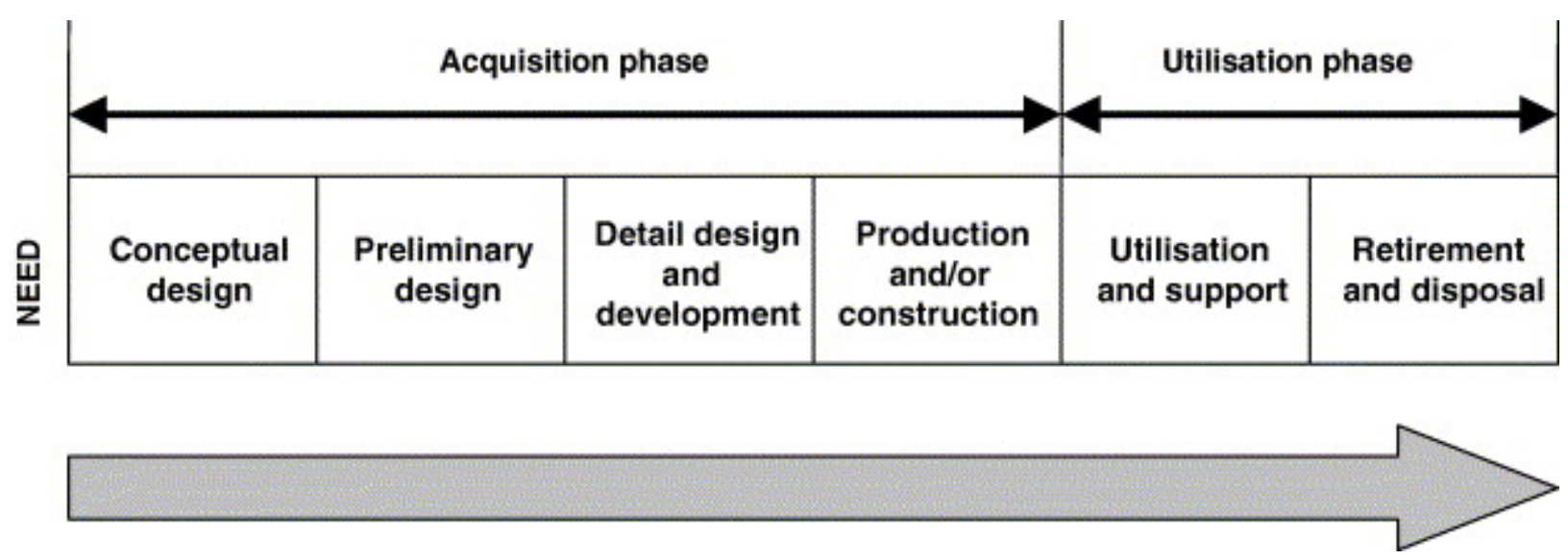

Fig. 4. Life cycle phases of process asset systems.

However, the asset that is implemented by a project can take various forms, for example, in the chemical industry the asset would normally be a new process or an entire plant. A typical plant life cycle also consists out of six phases, namely: two design phases, a construction phase, a start-up/commissioning phase, operation/maintenance phase, and then a decommissioning phase [21].

The asset life cycle can be simplified to four phases if all design phases are treated as one phase and start-up and commissioning are treated as part of the operational phase (see Fig. 5). The design phase of an asset can be the selection phase of manufacturing equipment if the asset is purchased and not an in-house design. 


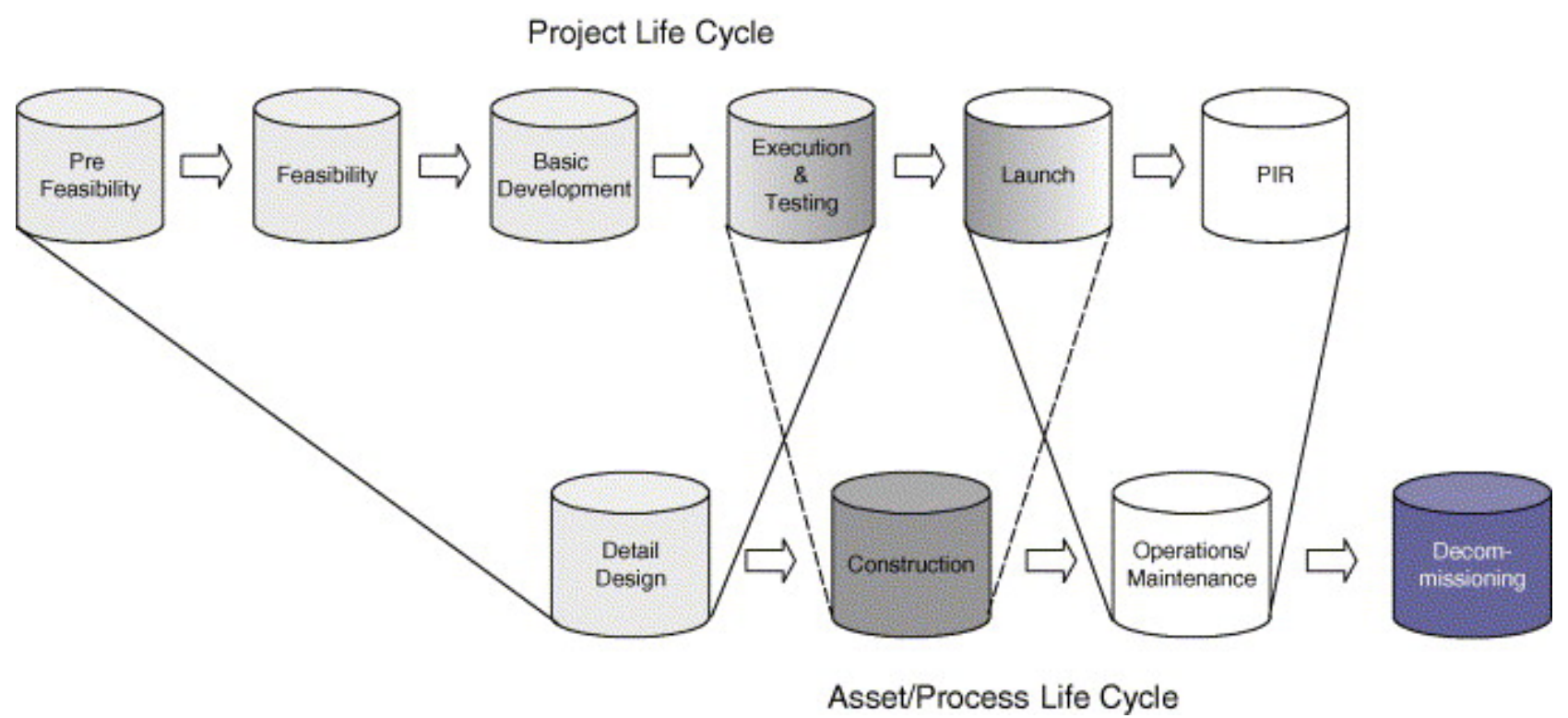

Fig. 5. Interaction between project and asset life cycle.

Since the project is the vehicle to design (if applicable) and implement the asset the two life cycles still interact. The project normally ends after the asset commences stable operations in accordance with performance requirements [31]. Therefore, the design, construction, and a small part of the operational phase are completed during the project's life cycle. A post-implementation review will take place when the asset is in its operational life cycle. Fig. 5 depicts this interaction.

\subsection{Product life cycle}

The main goal with the implementation of a new asset is to manufacture a product or to improve the manufacturing of a product that can meet the needs of a customer. The operational phase of the asset life cycle is thus the manufacturing or production phase of the product. In recent years product life cycles played an important role in the field of life cycle assessment (LCA), which is used to evaluate the environmental performances of products [32]. A product life cycle consisting out of 5 phases has been proposed from the perspective of LCA [33]. These phases are: Pre-manufacturing, Product Manufacturing, Product Delivery, Product Use and Refurbishment, and Recycling and Disposal. Another approach is to apply the generic systems life cycle (depicted in Fig. 4) to products [34]. 
The difference between these two life cycles is that the first uses a supply chain perspective and excludes the design phase of a product while the second starts the life cycle of a product with the need identification, and considers supply chain activities as part of the production phase. A simplified supply chain focused product life cycle is used to describe the interaction between the product and asset life cycles in Fig. 6.

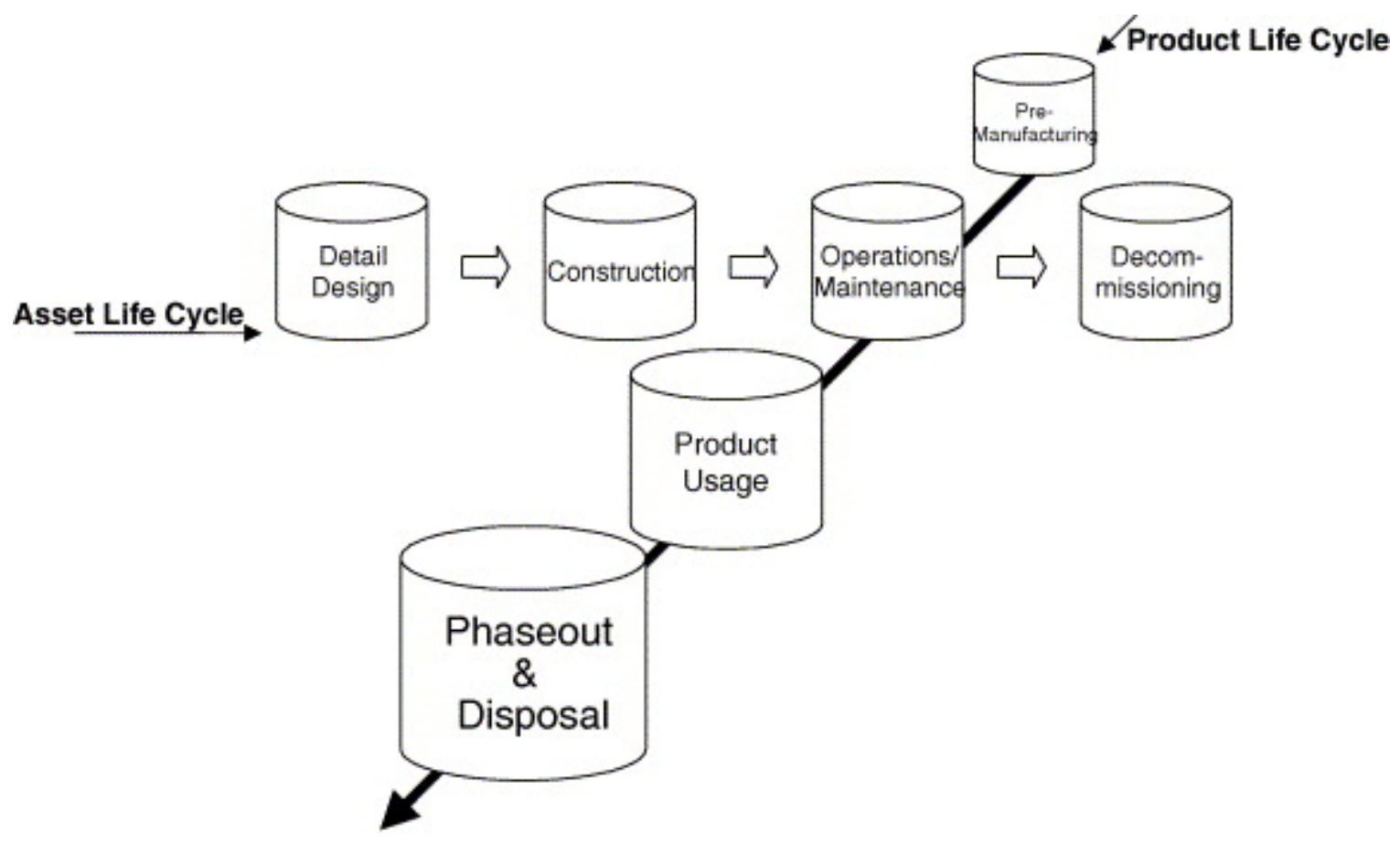

Fig. 6. Interaction between the product and asset life cycle.

\section{Sustainable Project Life Cycle Management: the way forward}

It is thus the asset life cycle resulting from the project, and the subsequent product life cycle resulting from the asset, that have economic, social and environmental consequences, which are in turn associated with an implemented project. Aligning project management (and appraisal) methodologies with the principles of sustainable development therefore requires that the sustainability consequences of these asset and product life cycles must be considered during the project life cycle. 
A comprehensive sustainability evaluation framework is therefore required to assess projects during the early life cycle phases in terms of sustainability consequences of the future implemented assets and products. Fig. 7 shows such a framework that has been developed, specifically for sustainability performance evaluations, which can be used in business processes [35]. The framework only shows the high level criteria that must be considered. Indicators for each criterion are needed and must then be utilized in the project appraisal process.

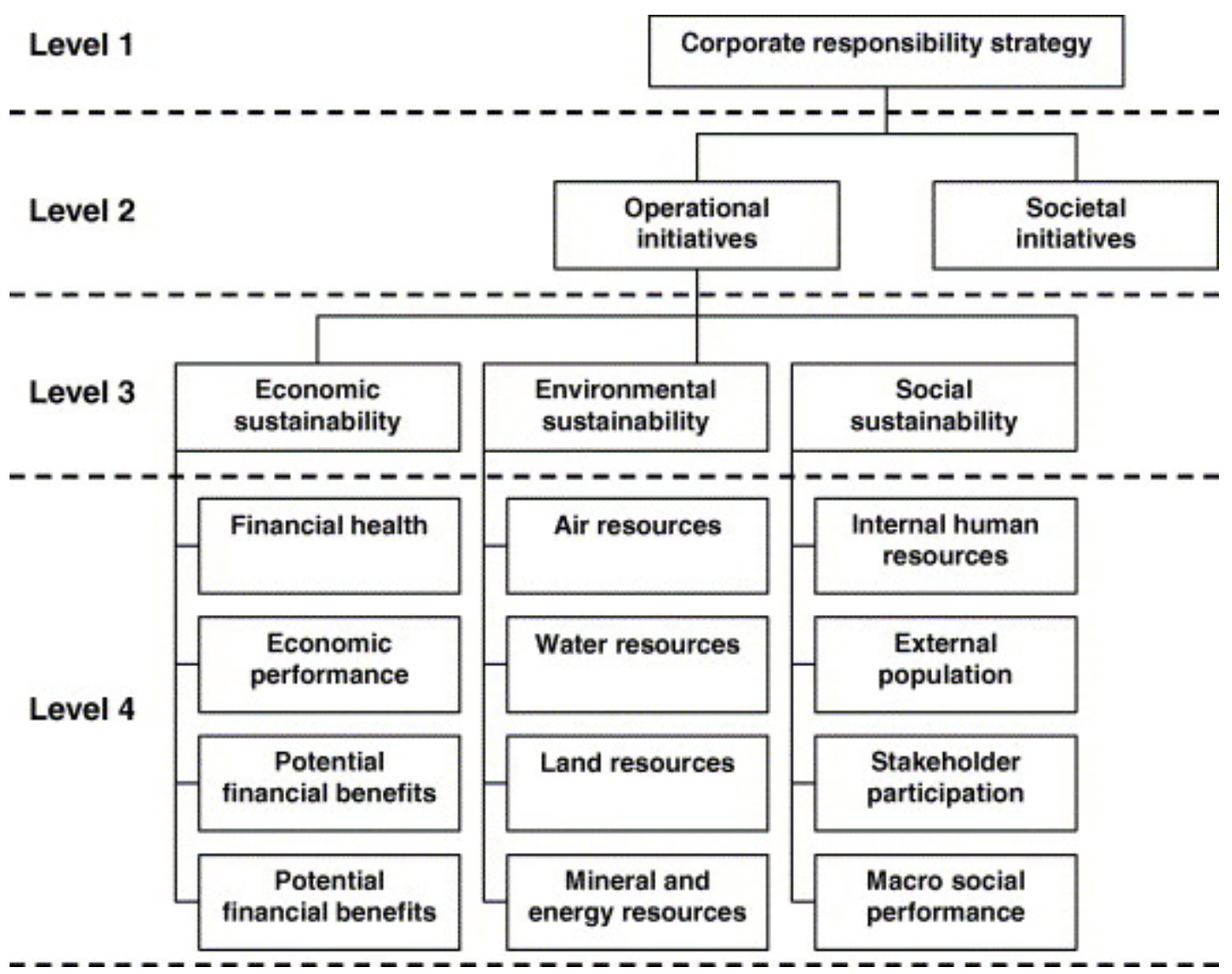

Fig. 7. Framework to assess the sustainability of operational activities.

\subsection{Identifying measurable indicators for the sustainability evaluation criteria}

The identification of suitable indicators to measure the impacts of an undertaken project (and the associated asset and product life cycles) on the three main sustainability dimensions (of Fig. 7) is dependent on the following three important points [35]:

- The kind of information that is available at the point of assessing the sustainability performance of a specific operational activity. For example, considering the life cycle of 
a technology development project in the process industry, detailed data may not exist in the early stages of the project on which to base an assessment, but may be available at later decision gates in the project appraisal process. Also, additional information gathering activities might have to be executed during individual phases in order to obtain the necessary sustainability data that is required by the indicators.

- The scientific methodology to translate the operational activity information. There is currently no consensus on the exact procedure to assess the environmental performances of operational activities. However, work is ongoing in this field and methodologies have been proposed. With respect to the social dimension, there is little agreement on which criteria should be considered for social performances evaluations and methodologies are currently not practical for industry applications and business practices. In contrast, the methodologies for most of the sub-criteria of the economic dimension are reasonably well defined.

- The preferences of the specific project appraisers. Two approaches are currently under debate. On the one hand all impacts could be translated into financial terms [36], which is often understandable by decision-makers. On the other hand, it is difficult, if not impossible, to place an economic value on all environmental and social impacts [37], and a qualitative route with decision analysis techniques, e.g., Multi-Criteria Decision Analysis (MCDA), could be used [38]. In some cases, a combination of these two approached have been proposed [39].

Based on these points, it is considered that the integration of existing and developed methodologies should be used in order to derive suitable indicators to measure the potential sustainability performances of implemented projects. Furthermore, the overall procedure (and subsequent indicators) would, most probably, be company-specific [35]. As far as the environmental dimension of sustainability is concerned, indicators have been proposed [40]. These indicators have been used as a basis to develop an Environmental Evaluation Matrix tool to apply in early project stages [41]. The matrix tool has been tested in the South African process industry by means of a case study [41]. 
Table 3 lists these environmental indicators as well as a number of possible social indicators.

Table 3.

Possible indicators for environmental and social criteria (see Fig. 7)

\begin{tabular}{|c|c|c|}
\hline Main citerion & Sub-citeria & Possible indicators \\
\hline \multirow[t]{4}{*}{ Air resources } & Regional air quality & - Acidification potential (kg SO $\mathrm{S}_{2}$ equivalents) \\
\hline & & $\begin{array}{l}\text { - Photochemical ozone creation potential }\left(\mathrm{kg} \mathrm{O}_{3}\right. \\
\text { equivalents) }\end{array}$ \\
\hline & Global air quality & - Global warming potential (kg CO 2 equivalents) \\
\hline & & $\begin{array}{l}\text { - Stratospheric ozone depletion potential (kg CFC-11 } \\
\text { equivalents) }\end{array}$ \\
\hline \multirow[t]{4}{*}{ Water resources } & Water quantity & $\begin{array}{l}\text { - Water use: surface and groundwater reserves (kg } \\
\text { water) }\end{array}$ \\
\hline & Water quality & • Eutrophication potential (kg $\mathrm{PO}_{4}$ equivalents) \\
\hline & & - Human toxicity potential (kg Pb equivalents) \\
\hline & & • Eco-toxicity potential (kg Pb equivalents) \\
\hline \multirow[t]{3}{*}{ Land resources } & Land quantity & - Land use: occupation or transformation (m² degraded) \\
\hline & Land quality & • Human toxicity potential (kg Pb equivalents) \\
\hline & & • Eco-toxicity potential (kg Pb equivalents) \\
\hline \multirow[t]{2}{*}{ Mineral resources } & Mineral reserves & • Mineral depletion (kg Pt equivalents) \\
\hline & Energy reserves & • Energy depletion (kg coal equivalents) \\
\hline \multirow[t]{3}{*}{$\begin{array}{l}\text { Internal human } \\
\text { resources }\end{array}$} & Employee stability & - Net number of permanent jobs created by project \\
\hline & & - Wages as a percentage of project budget \\
\hline & Employment practices & • Average working hours \\
\hline
\end{tabular}




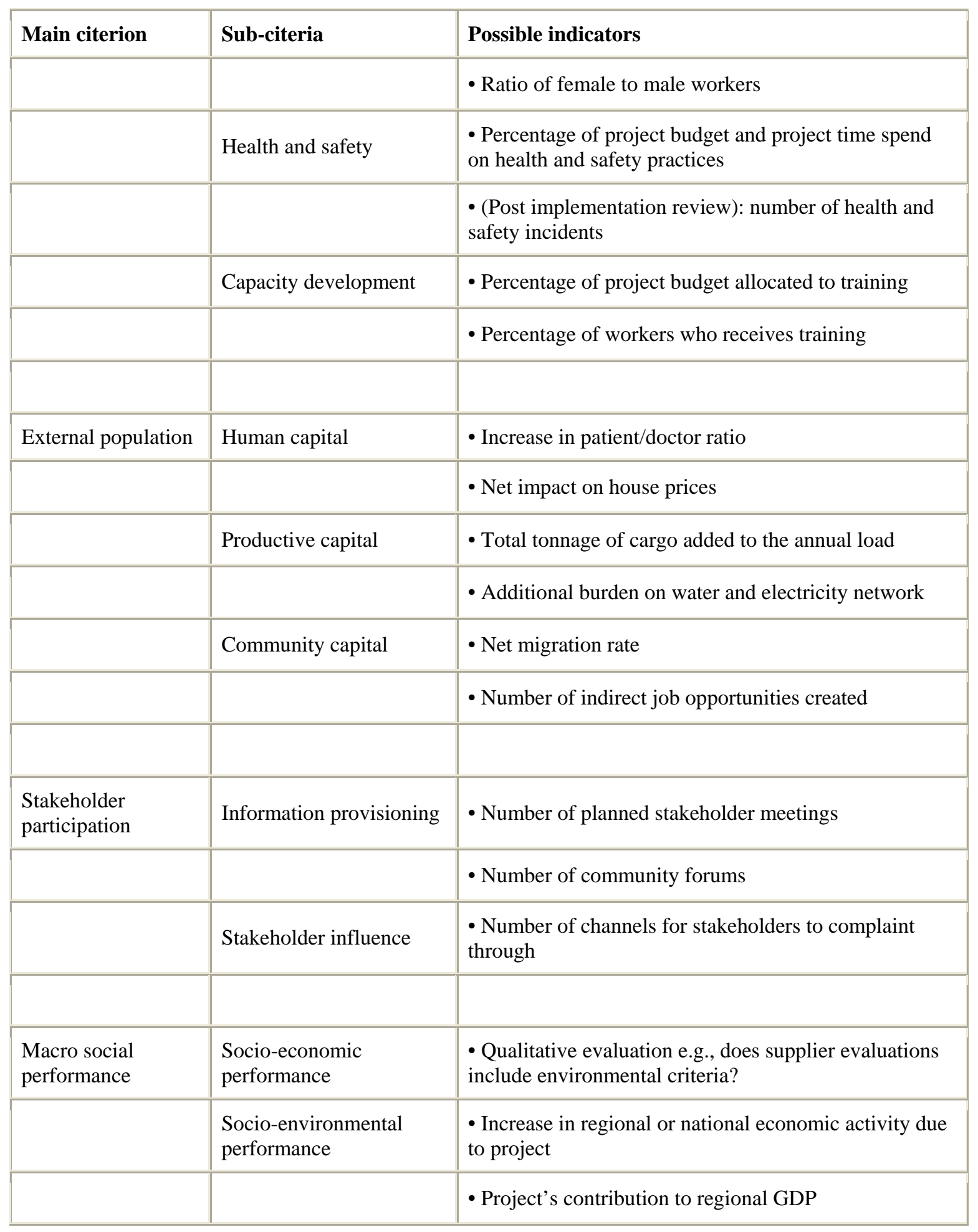

\subsection{Further work required}

In conclusion, the following work is required to develop a Sustainable Project Life Cycle Management methodology: 
- Indicators for the social sustainability criteria (of Table 3) must be refined and are in a process of development. The methodology that will be followed relies on expert panels to determine which social sub-criteria should be dealt with in a corporate governance framework for projects and which in a project itself.

- Furthermore, calculated indicators for project specific criteria are constraint by the type of information that is available (pertaining to the asset and product life cycles) in each project life cycle phase, as well as the available data in the society in which a project is deployed. Case studies of the different asset life cycle phases are being undertaken to establish the suitability of the calculated indicators for projects in the South African process industry.

- The social and environmental indicators must be incorporated into real time project appraisals and decision-making processes to assess the relevance of introducing the indicators into project management methodologies.

The global sustainability trend is forcing companies to internalise social and environmental externalities [42]. The aim of the proposed future work is to ensure that project management methodologies facilitate this internalisation.

\section{References}

[1] D. Mebratu, Sustainability and sustainable development: historical and conceptual review, Environ. Impact Assess. Rev. 18 (1998), pp. 493-520.

[2] The World Summit on Sustainable Development. Sustainable Development Summit Concludes in Johannesburg: UN Secretary-General Kofi Annan Says It's Just the Beginning. Retrieved on 6 November 2003 from the World Wide Web: http://www.johannesburgsummit.org/html/whats_new/feature_story39.htm.

[3] H.E. Daly, Toward some operational principles of sustainable development, Ecol. Econ. 2 (1990), pp. 1-6.

[4] Sampson I. Introduction to a legal framework to pollution management in South Africa. South Africa: Water Research Commission, No. TT149/01: Deloitte \& Touche and WRC Report, 2001. 
[5] A. Azapagic and S. Perdan, Indicators of sustainable development for industry, Trans. Ichem. B 78 (2000), pp. 243-261.

[6] M. Sillanpää, A new deal for sustainable development in business. In: M. Bennett and P. James, Editors, Sustainable measures, Greenleaf Publishing, Sheffield (1999). [7] IISD, Global Responsibility. The sustainable development journey. Retrieved on 6 November 2003 from the World Wide Web: http://www.bsdglobal.com/sd_journey.asp. [8] H. Briassoulis, Sustainable development and its indicators: through a (planner's) glass darkly, J. Environ. Planning Manage. 44 (2001) (3), pp. 409-427

[9] S.L. Wartick and D.J. Wood, International business and society, Blackwell, Malden, MA (1998).

[10] C.O. Holliday, S. Schmidheiny and P. Watts, Walking the talk: the business case for sustainable development, Greenleaf Publishing, Sheffield (2002).

[11] J.J. Keeble, S. Topiol and S. Berkeley, Using indicators to measure sustainability performance at a corporate and project level, J. Bus. Ethics 44 (2003), pp. 149-158. [12] Goede F. The Future of SH\&E in the process industry with the focus on products. Presentation given at the Department of Engineering and Technology Management, University of Pretoria, South Africa, 18 August 2003.

[13] International Institute for Sustainable Development, Deloitte \& Touche and the World Business Council for Sustainable Development. Business Strategies for Sustainable Development: Leadership and Accountability for the 90s. Retrieved from: http://www.iisd.org/publications/publication.asp?pno=242; 2003 [accessed on 2 April]. [14] Du Toit AJ. Advanced Planning Implementation Project Management Methodology. Pretoria: Unpublished Masters Thesis, University of Pretoria, 2004. [15] PricewaterhouseCoopers. 2002 Sustainability Survey Report. PricewaterhouseCoopers, August 2002.

[16] Bieker T, Dyllick T, Gminder CU, Hockerts K. Towards a sustainability Balanced Scorecard linking environmental and social sustainability to business strategy. In: Proceedings of the 2001 business strategy and the environment conference held at the University of Leeds, UK, 10 \& 11 September, 2001. 
[17] T.N. Gladwin, J.J. Kennelly and T.-S. Krause, Shifting paradigms for sustainable development: implications for management theory and research, Acad. Manage. Rev. 20 (1995) (4), pp. 874-907.

[18] Project Management Institute. PMBOK ${ }^{\circledR}$ guide: a guide to project management body of knowledge. Retrieved on 5 November 2003 from the World Wide Web: http://www.pmi.org.

[19] H. Kerzner, Project management: a systems approach to planning, scheduling and controlling, Wiley, New York (2001).

[20] R. Buttrick, The project workout: a toolkit for reaping the rewards from all your business projects, Prentice Hall, London (2000).

[21] Labuschagne C. Sustainable Project Life Cycle Management: criteria for the South African process industry. Masters Thesis, Department of Industrial and Systems Engineering, University of Pretoria, South Africa, 2003.

[22] Department of Environmental Affairs and Tourism. Guideline Document: EIA Regulations: Implementation of Sections 21, 22 and 26 of the Environmental Conservation Act. Pretoria: Department of Environmental Affairs and Tourism, April 1998.

[23] M.D.S. Lopes and R. Flavell, Project appraisal: a framework to access non-financial aspects of projects during the project life cycle, Int. J. Project Manage. 16 (1998) (4), pp. 223-233.

[24] M.J.F. Van Pelt, Ecologically sustainable development and project appraisal in developing countries, Ecol. Econ. 7 (1993) (1), pp. 19-42.

[25] Warhurst A. Sustainability indicators and sustainability performance management. Mining, Minerals and Sustainable Development Paper No. 43, March, 2003.

[26] D.S. Remer and A.P. Nieto, A compendium and comparison of 25 project evaluation techniques, Int. J. Prod. Econ. 42 (1995) (1-2), pp. 79-129.

[27] P. Bonnal, D. Gourc and G. Lacoste, The life cycle of technical projects, Project Manage. J. 33 (2002) (1), pp. 12-19.

[28] R.L. Kliem, I.S. Ludin and K.L. Robertson, Project management methodology: a practical guide for the next millennium, Marcel Dekker, New York (1997). 
[29] B.S. Blanchard, Logistics engineering and management (5th ed.), Prentice Hall International, New Jersey (1998).

[30] Schuman CA, Brent AC. Asset life cycle management: towards improving asset performance. Department of Engineering and Technology Management Working Paper ITB2003/4. Pretoria: University of Pretoria, 2003.

[31] J. Dingle, Project management: orientation for decision makers, Arnold, London (1997).

[32] UNEP Sustainable Consumption. Life Cycle Initiative. Retrieved on 6 November 2003 from the World Wide Web:

http://www.uneptie.org/pc/sustain/lcinitiative/home.htm.

[33] T.E. Graedel, Streamlined life-cycle assessment, Prentice Hall, New Jersey (1998).

[34] B.S. Blanchard and W.J. Fabrycky, Systems engineering and analysis (3rd ed.), Prentice Hall International, New Jersey (1998).

[35] Labuschagne C, Brent AC, Van Erck RPG. Assessing the sustainability performances of industry. J Cleaner Prod [in press].

[36] Van Erck R. A monetary evaluation of the sustainability of GTL fuel production in South Africa. Master's Thesis, Faculty of Technology Management, Technical University Eindhoven, October, 2003.

[37] R. Jansen, Multi-objective decision support for environmental management, Kluwer Academic Publishers, Dordrecht (1992).

[38] Petrie J, Basson L, Stewart M, Notten P, Alexander B. Decision making for design of cleaner processes: a life cycle management perspective. In: Proceedings of the first international conference on life cycle management: bridging the gap between science and application; 2001.

[39] J.T. Winpenny, Values for the environment: a guide to economic appraisal, HMSO, London (1991).

[40] A.C. Brent, A proposed lifecycle impact assessment framework for South Africa from available environmental data, South African J. Sci. 99 (2003), pp. 115-122.

[41] Labuschagne C, Brent AC. Sustainable Project Life Cycle Management: aligning project management methodologies with the principles of sustainable development. In: 
Proceedings of the 2004 PMSA international conference, 10-12 May, 2004.

Johannesburg, South Africa. p. 104-15.

[42] W. Visser and C. Sunter, Beyond reasonable greed: why sustainable business is a much better idea!, Human \& Rousseau Tafelberg, Cape Town (2002).

Corresponding author. Tel.: +27 12420 3929; fax: +27 123625307 